\title{
Asupan Energi, Protein dan Lemak dengan Kejadian Gizi Kurang pada Balita Usia 24-59 Bulan di Desa Suci, Gresik
}

\section{Energy, Protein and Fat Intake with Underweight of Toddlers Age 24-59 Months in Suci Village, Gresik}

Shafira Roshmita Diniyyah*1, Triska Susila Nindya ${ }^{1}$

\begin{abstract}
ABSTRAK
Latar Belakang: Gizi kurang masih menjadi masalah gizi utama di Indonesia. Balita merupakan salah satu kelompok usia yang rentan mengalami masalah gizi. Penyebab langsung terjadinya gizi kurang salah satunya dipengaruhi oleh asupan zat gizi. Asupan energi, protein dan lemak yang rendah menyebabkan pemanfaatan zat gizi tidak optimal dan rentan mengalami penyakit infeksi.

Tujuan: Tujuan dari penelitian ini adalah menganalisis hubungan asupan energi, protein dan lemak dengan kejadian gizi kurang balita usia 24-59 bulan.

Metode: Penelitian ini menggunakan desain studi cross sectional dengan jumlah sampel 62 balita yang tinggal di wilayah Desa Suci Gresik. Pengumpulan data dilakukan dengan wawancara dengan kuesioner terk1q'3aq15b'6aait karakteristik balita dan orangtua, form food recall $2 \times 24$ jam dan pengukuran berat badan balita menggunakan indikator BB/U. Data dianalisis menggunakan uji fisher exact.

Hasil: Hasil dari penelitian ini menunjukkan balita dengan status gizi baik $79,0 \%$ dan balita gizi kurang $21,0 \%$. Sebagian besar balita memiliki tingkat asupan energi, lemak dan protein dalam kategori cukup. Terdapat hubungan antara asupan energi $(p=0,007)$, protein $(p=0,039)$ dan lemak $(p=0,010)$ dengan status gizi balita berdasarkan indeks $B B / U$.

Kesimpulan: Balita gizi kurang memiliki tingkat asupan energi, protein dan lemak lebih rendah dibandingkan dengan balita gizi baik. Perlu meningkatkan asupan bahan makanan sumber energi, protein dan lemak yang tinggi serta bervariasi agar kondisi gizi kurang tidak semakin memburuk.
\end{abstract}

Kata Kunci: asupan energi, gizi kurang, lemak, protein 


\begin{abstract}
Background: Undernutrition is still the major of nutritional problem in Indonesia. Toddlers are one of age group that are susceptible to nutritional problems. One of the direct cause of malnutrition is nutrient intake. Low intake of energy, protein and fat causes the utilization of nutrient intake become not optimal and susceptible to infectious diseases.

Objectives: The purpose of this study was to analyze the correlation between energy, protein and fat intake with underweight toddlers aged 24-59 months.

Methods: This research used a cross sectional study design with a sample size of 62 toddlers that living in the Suci Village Gresik. Data were collected by interview with questionnaires that related to the characteristic of toddlers and parents, form food recall $2 \times 24$ hours and measurement of weight toddlers based on WAZ index. Data were analyzed using fisher exact test.

Results: Underweight toddlers have lower intake of energy, protein and fat intake than non underweight toddlers. The results showed that there are $79.0 \%$ non underweight toddlers and $21.0 \%$ underweight, most of toddlers have adequate levels of energy, protein and fat intake. There was a correlation between energy $(p=0.007)$, protein $(p=0.039)$ and fat intake $(p=0.010)$ with nutritional status of toddlers based on WAZ index.

Conclusions: It was suggested to increase the varied and food sources of high energy, protein and fat, so the malnutrition can't getting worse.
\end{abstract}

Keywords: energy intake, undernutrition, fat, protein

\footnotetext{
* Koresponden:

roshmitashafira@gmail.com

${ }^{1}$ Departemen Gizi Kesehatan, Fakultas

Kesehatan Masyarakat-Universitas Airlangga
} 


\section{PENDAHULUAN}

Gizi kurang merupakan suatu kondisi berat badan menurut umur (BB/U) tidak sesuai dengan usia yang seharusnya ${ }^{1}$. Kondisi gizi kurang rentan terjadi pada balita usia 2-5 tahun karena balita sudah menerapkan pola makan seperti makanan keluarga dan mulai dengan tingkat aktivitas fisik yang tinggi. Kekurangan gizi pada masa balita terkait dengan perkembangan otak sehingga dapat mempengaruhi kecerdasan anak dan berdampak pada pembentukan kualitas sumber daya manusia di masa mendatang ${ }^{2}$

Pada tahun 2013 kejadian balita gizi kurang di Gresik menunjukkan angka 5,83\% sedangkan pada tahun sebelumnya prevalensi gizi kurang yaitu 5,61\% ${ }^{3}$. Pada tahun 2014 didapatkan jumlah balita dengan gizi buruk sejumlah 28 balita. Hal tersebut membuktikan bahwa masih terdapat masalah gizi kurang dan gizi buruk di kota Gresik dengan ditandainya peningkatan prevalensi dari tahun sebelumnya.

Asupan zat gizi merupakan salah satu penyebab langsung yang dapat mempengaruhi status gizi balita ${ }^{4}$. Asupan zat gizi dapat diperoleh dari beberapa zat gizi, diantaranya yaitu zat gizi makro seperti energi karbohidrat protein dan lemak. Zat gizi makro merupakan zat gizi yang dibutuhkan dalam jumlah besar oleh tubuh dan sebagian besar berperan dalam penyediaan energi ${ }^{5}$. Tingkat konsumsi zat gizi makro dapat mempengaruhi terhadap status gizi balita. Hal tersebut didukung oleh penelitian sebelumnya bahwa terdapat hubungan antara tingkat konsumsi energi dan protein dengan status gizi balita. Balita dengan tingkat konsumsi energi dan protein yang mencukupi dan memenuhi kebutuhan tubuh akan berbanding lurus dengan status gizi baik ${ }^{6}$. Penelitian sebelumnya juga menyebutkan bahwa asupan energi dan protein yang rendah berdampak pada meningkatnya resiko masalah gizi seperti kekurangan energi kronis dan kekurangan energi protein, selain pada balita dapat berdampak pada terhambatnya pertumbuhan dan perkembangan kognitifnya. Asupan lemak yang rendah juga menyebabkan terjadinya penurunan massa tubuh dan gangguan pada penyerapan vitamin larut lemak ${ }^{5}$. Ketidakseimbangan tingkat konsumsi zat gizi makro seperti energi, karbohidrat lemak dan protein terhadap kebutuhan tubuh secara berkepanjangan dapat mempengaruhi terjadinya perubahan pada jaringan dan massa tubuh yang akan berdampak pada penurunan berat badan (berat badan kurang) ${ }^{7}$.

Hal diatas menjelaskan bahwa Gresik merupakan salah satu kota yang masih memiliki jumlah prevalensi balita gizi kurang dan gizi buruk yang cukup tinggi. Berdasarkan uraian tersebut, diperlukan adanya penelitian untuk mengetahui hubungan asupan energi, lemak dan protein dengan kejadian gizi kurang pada balita usia 24-59 bulan di Kabupaten Gresik.

\section{METODE}

Penelitian ini merupakan jenis penelitian observasional analitik dengan desain studi cross sectional. Sampel dalam penelitian ini adalah 62 balita yang didapatkan melalui perhitungan rumus Lameshow dengan kriteria inklusi yaitu balita berusia 24-59 bulan yang sehat dan tidak memiliki cacat bawaan lahir. Pengambilan sampel dalam penelitian ini menggunakan metode simple random sampling di Desa Suci yang merupakan wilayah kerja dari Puskesmas Sukomulyo Gresik. Variabel dalam penelitian ini dibagi menjadi dua yaitu variabel bebas yang terdiri dari asupan energi, protein dan lemak sedangkan variabel terikat yang diteliti adalah status gizi balita berdasarkan indeks BB/U.

Karakteristik balita dalam penelitian ini terdiri dari usia, jenis kelamin dan berat badan lahir. Karakteristik keluarga yang ditanyakan adalah pendidikan orang tua, pekerjaan orang tua, jumlah anggota keluarga dan pendapatan keluarga. Data yang dikumpulkan yaitu data primer dan data sekunder. Data primer didapatkan dari hasil pengukuran berat badan balita menggunakan timbangan digital, wawancara dengan kuesioner dan form food recall 2×24 jam. Data sekunder meliputi jumlah balita usia 24-59 bulan yang terdaftar di Desa 
Suci dan dipatkan melalui data Puskesmas Sukomulyo Gresik.

Hasil pengukuran berat badan balita menggunakan indeks $\mathrm{BB} / \mathrm{U}$ dan dibandingkan dengan nilai z-score serta diklasifikasikan menjadi dua kategori yaitu gizi kurang jika termasuk dalam kategori gizi kurang dan gizi buruk serta gizi baik jika termasuk dalam kategori gizi baik dan gizi lebih. Recall $2 \times 24$ jam dilakukan pada dua hari dan tidak berurutan, asupan energi, protein dan lemak dibandingkan dengan cut off poin Estimated Average Requirement (EAR) yaitu kategori kurang jika $<77 \%$ AKG dan kategori cukup $\geq 77 \%$ AKG. Hasil dari penelitian ini dianalisis menggunakan analisis univariat dan bivariat. Analisis univariat dilakukan untuk melihat distribusi frekuensi dari karakteristik balita, keluarga dan variabel asupan. Analisis bivariat dilakukan untuk mengetahui hubungan antar variabel yang diteliti dengan menggunakan uji fisher exact $(\alpha=0,05)$. Penelitian ini telah lulus etik oleh Komisi Etik Fakultas Kesehatan Masyarakat Universitas Airlangga Surabaya dengan sertifikat etik no 217-KEPK pada tanggal 15 Mei 2017.

\section{HASIL DAN PEMBAHASAN}

Karakteristik balita dan keluarga pada tabel 1 menunjukkan bahwa sebagian besar balita dalam penelitian ini berusia 24-36 bulan yaitu 24 balita $(38,7 \%)$. Pada kelompok umur tersebut masalah gizi seperti seperti underweight, stunting maupun wasting rentan terjadi pada balita. Umur 2 tahun balita juga sudah memasuki masa penyapihan dan menerapkan pola makan seperti orang tua sehingga asupan makanan sangat penting dibutuhkan untuk menunjang proses pertumbuhan balita ${ }^{8}$.

Tabel 1. Distribusi Karakteristik Balita dan Keluarga di Desa Suci Tahun 2017

\begin{tabular}{|c|c|c|}
\hline Karakteristik & $\mathbf{n}$ & $\%$ \\
\hline \multicolumn{3}{|l|}{ Usia Balita (bulan) } \\
\hline $24-36$ & 24 & 38,7 \\
\hline $37-48$ & 20 & 32,3 \\
\hline 49-59 & 18 & 29,0 \\
\hline Total & 62 & 100,0 \\
\hline \multicolumn{3}{|l|}{ Jenis Kelamin Balita } \\
\hline Laki-laki & 36 & 58,1 \\
\hline Perempuan & 26 & 41,9 \\
\hline Total & 62 & 100,0 \\
\hline \multicolumn{3}{|l|}{ Berat Badan Lahir } \\
\hline Normal ( $\geq 2.500$ gram) & 61 & 98,4 \\
\hline Rendah (<2.500 gram) & 1 & 1,6 \\
\hline Total & 62 & 100,0 \\
\hline \multicolumn{3}{|l|}{ Jumlah Anggota Keluarga } \\
\hline Besar (>4 orang) & 28 & 45,2 \\
\hline Kecil ( $\leq 4$ orang) & 34 & 54,8 \\
\hline Total & 62 & 100,0 \\
\hline \multicolumn{3}{|l|}{ Pendapatan Keluarga } \\
\hline$<U M K$ & 12 & 19,4 \\
\hline$\geq U M K$ & 50 & 80,6 \\
\hline Total & 62 & 100,0 \\
\hline
\end{tabular}


Jenis kelamin balita pada penelitian ini sebagian besar adalah laki-laki yaitu sebanyak 36 balita $(58,1 \%)$. Penelitian di Ghana menyebutkan bahwa anak perempuan lebih besar mengalami resiko masalah gizi dibandingkan dengan anak laki-laki ${ }^{9}$. Hal tersebut dikarenakan terdapat perbedaan prioritas keluarga dalam pemberian pola asuh, pola makan dan perawatan pada anak laki-laki dibandingkan anak perempuan ${ }^{9}$.

Mayoritas balita dalam penelitian ini lahir dengan berat badan lahir normal $(\geq 2.500$ gram). Balita dengan berat badan lahir normal yaitu sebanyak 61 balita $(98,4 \%)$ namun terdapat $1,6 \%$ balita lahir dengan BBLR. Berat badan lahir rendah balita menyebabkan meningkatkan resiko terjadinya underweight, terhambatnya tumbuh kembang dan memiliki resiko lebih besar mengalami penyakit seperti jantung, hipertensi dan penyakit infeksi ketika usia remaja atau dewasa ${ }^{10}$. Hal tersebut diperkuat dengan hasil penelitian sebelumnya bahwa berat badan lahir rendah meningkatkan resiko 2,94 kali lebih besar balita mengalami kekurangan gizi pada masa anak-anak dibandingkan dengan balita dengan berat badan lahir normal ${ }^{11}$.

Tabel 1 memperlihatkan hasil bahwa sebagian besar keluarga balita memiliki jumlah anggota keluarga dalam kategori keluarga kecil ( $\leq 4$ orang) yaitu sebanyak 34 keluarga $(54,8 \%$ ) sedangkan balita yang termasuk dalam kategori keluarga besar (>4orang) sejumlah 28 $(45,2 \%)$. Hal tersebut menunjukkan bahwa balita dari keluarga besar maupun kecil memiliki selisih presentase yang tidak terlalu jauh. Jumlah anggota di dalam suatu keluarga dapat menyebabkan kurang optimalnya distribusi dan tingkat konsumsi makanan. Keluarga dengan jumlah anggota yang besar cenderung akan mendapatkan bagian kecil dari makanan yang tersedia ${ }^{12 .}$ Kurangnya ketersediaan makanan dalam waktu yang berkepanjangan dapat mempengaruhi rendahnya tingkat konsumsi makanan dan berdampak pada kekurangan gizi. Selain itu keluarga dengan jumlah anggota yang besar (memiliki jumlah anak yang besar) menyebabkan kurangnya perhatian ibu pada pola asuh dan perawatan anak.
Sebagian besar keluarga balita memiliki tingkat pendapatan $\geq$ UMK Gresik yaitu sebanyak 50 keluarga $(80,6 \%)$ namun masih terdapat 12 keluarga $(19,4 \%)$ dengan tingkat pendapatan <UMK Gresik. Pendapatan merupakan salah satu indikator yang dapat dijadikan sebagai akses untuk mempermudah dalam memenuhi kebutuhan seperti membeli makanan, mendapatkan informasi, pelayanan kesehatan serta sarana tempat tinggal dan air yang bersih ${ }^{13}$. Keluarga dengan tingkat pendapatan yang tinggi akan lebih mudah dalam mendapatkan akses tersebut. Pendapatan juga salah satu faktor yang berperan dalam mempengaruhi daya beli seseorang serta pemilihan bahan makanan secara berkualitas. Penelitian sebelumnya menyebutkan bahwa keluarga dengan pendapatan yang rendah cenderung membelanjakan sebagian besar penghasilannya untuk kebutuhan pangan keluarga ${ }^{14}$.

Tingkat pendapatan keluarga merupakan salah satu indikator sosial ekonomi yang berperan dalam penyediaan bahan makanan dan pola makan keluarga, pendapatan juga berpengaruh pada tingkat pengeluaran pangan yang dikeluarkan suatu keluarga ${ }^{13}$. Rendahnya pendapatan dapat menjadi salah satu faktor penyebab terjadinya status gizi kurang balita, dikarenakan apabila jumlah pendapatan rendah, maka tingkat pengeluaran pangan juga rendah sehingga dapat menyebabkan rendahnya daya beli dan ketersediaan bahan pangan yang berperan terhadap tingkat konsumsi gizi balita yang tidak optimal ${ }^{14}$.

Rendahnya tingkat konsumsi zat gizi secara terus-menerus pada balita pada akhirnya dapat meningkatkan resiko trejadinya malnutrisi ${ }^{1}$. Hal itu dikuatkan dengan penelitian lain yang menyebutkan bahwa anakanak yang berasal dari keluarga dengan ekonomi rendah memiliki tubuh lebih kurus dan pendek dibandingkan dengan anak yang berasal dari keluarga dengan tingkat ekonomi tingg $i^{15}$.

Tabel 2 menunjukkan bahwa tingkat asupan energi, lemak dan protein pada balita sebagian besar termasuk dalam kategori cukup. Asupan energi balita dalam kategori 
cukup sebanyak 44 balita (71\%). Proporsi balita dengan asupan energi yang cukup dan memiliki status gizi baik $(88,6 \%)$ lebih tinggi dibandingkan dengan balita dengan asupan energi yang cukup dan memiliki status gizi kurang $(11,4 \%)$. Berdasarkan uji fisher exact didapatkan bahwa terdapat hubungan yang signifikan antara asupan energi dengan status gizi balita dengan nilai $p=0,007$. Hal tersebut sesuai dengan penelitian sebelumnya bahwa energi memiliki hubungan yang signifikan dengan status gizi balita menurut indeks $\mathrm{BB} / \mathrm{U}^{16}$. Penelitian lain pada balita usia 7-59 bulan juga menyebutkan bahwa tingkat asupan energi yang rendah pada balita dalam jangka waktu lama menyebabkan peningkatan resiko 2,9 kali lebih besar mengalami kurang gizi $^{17}$.

Asupan energi yang tidak mencukupi kebutuhan dapat menyebabkan terjadinya ketidakseimbangan energi. Ketidakseimbangan energi secara berkepanjangan menyebabkan terjadinya masalah gizi seperti kekurangan energi kronis (KEK) serta berdampak pada perubahan berat badan seseorang?

Balita dengan tingkat asupan energi yang rendah mempengaruhi pada fungsi dan struktural perkembangan otak serta dapat mengakibatkan pertumbuhan dan perkembangan kognitif yang terhambat ${ }^{17}$. Energi yang berasal dari makanan dapat diperoleh dari beberapa zat gizi makro yaitu karbohidrat, protein dan lemak. Energi memiliki fungsi sebagai penunjang proses pertumbuhan, metabolisme tubuh dan berperan dalam proses aktivitas fisik ${ }^{7}$.

Tabel 2 menunjukkan bahwa balita dengan asupan protein yang cukup sebanyak 43 balita $(69,4 \%)$ sedangkan 19 balita lainnya memiliki asupan protein yang kurang $(30,6 \%)$. Jumlah balita yang memiliki status gizi baik dengan tingkat asupan protein yang cukup (72,1\%) lebih banyak dibandingkan dengan balita yang memiliki status gizi baik namun asupan proteinnya kurang.

Berdasarkan hasil uji statistik didapatkan bahwa nilai $p=0,039$ yang berarti terdapat hubungan antara tingkat asupan protein dengan status gizi balita. Hal ini sejalan dengan penelitian sebelumnya bahwa semakin baik tingkat asupan protein balita maka status gizi balita akan semakin baik juga ${ }^{6}$. Hal tersebut juga didukung oleh penelitian lainnya yang menyimpulkan bahwa tingkat asupan protein yang rendah pada balita meningkatkan resiko 3,1 kali mengalami kejadian underweight dibandingkan dengan balita yang memiliki tingkat kecukupan protein yang baik ${ }^{17}$.

Protein merupakan salah satu zat gizi makro yang berfungsi sebagai zat pembangun, pemelihara sel dan jaringan tubuh serta membantu dalam metabolisme sistem kekebalan tubuh seseorang ${ }^{5}$. Protein yang berasal dari makanan akan dicerna dan diubah menjadi asam amino yang berfungsi sebagai

Tabel 2. Distribusi Tingkat Asupan Energi, Lemak dan Protein Pada Balita di Desa Suci Tahun 2017

\begin{tabular}{lcc}
\hline \multicolumn{1}{c}{ Asupan Balita } & $\mathbf{n}$ & $\%$ \\
\hline Energi & & \\
$\quad$ Cukup & 44 & 71,0 \\
$\quad$ Kurang & 18 & 29,0 \\
\hline Total & 62 & 100,0 \\
\hline Lemak & & \\
$\quad$ Cukup & 34 & 54,8 \\
$\quad$ Kurang & 28 & 45,2 \\
\hline Total & 62 & 100,0 \\
\hline Protein & & \\
$\quad$ Cukup & 43 & 69,4 \\
$\quad$ Kurang & 19 & 30,6 \\
\hline Total & 62 & 100,0 \\
\hline
\end{tabular}


prekursor dari neurotransmitter dan berperan dalam perkembangan otak anak ${ }^{18}$. Protein erat kaitannya dengan sistem kekebalan tubuh, asupan protein yang rendah menyebabkan gangguan pada mukosa, menurunnya sistem imun sehingga mudah terserang penyakit infeksi seperti infeksi saluran pencernaan dan pernafasan ${ }^{17}$.

Penyakit infeksi yang sering diderita oleh balita adalah diare dan gejala infeksi saluran pernafasan akut (ISPA), gejala ISPA yang ditimbulkan dapat berupa batuk, sesak nafas dan demam sehingga dapat menyebabkan balita kurang tidur dan menganggu aktivitas sehari-hari ${ }^{19}$.

Diare juga merupakan salah satu penyakit infeksi yang berperan dalam kejadian malnutrisi. Diare disertai dengan gejala mual dan muntah dapat meningkatkan kehilangan cairan tubuh yang berdampak pada dehidrasi dan penurunan berat badan seseorang ${ }^{10}$. Hal tersebut apabila berlangsung dalam jangka waktu yang panjang dapat memperparah kondisi gizi kurang dan meningkatkan terjadinya kondisi gizi buruk balita. Selain itu diare menyebabkan penurunan nafsu makan sehingga asupan zat gizi rendah yang mengakibatkan pada penyerapan dan pemanfaatan zat gizi seperti energi, karbohidrat, lemak dan protein berjalan tidak optimal $^{7}$. Selain kejadian penyakit infeksi yang ditimbulkan akibat kurangnya asupan protein, masalah lain yang dapat terjadi akibat kekurangan protein disertai dengan energi adalah kekurangan energi protein (KEP), kondisi kekurangan energi dan protein pada balita dan anak-anak menyebabkan gangguan pada perkembangan kognitif yang berdampak pada kecerdasan otak anak ${ }^{18}$.

Berdasarkan tabel 2 mayoritas balita memiliki tingkat asupan lemak yang cukup yaitu sebanyak 34 balita $(54,8 \%)$. Jumlah balita dengan asupan lemak yang cukup dan memiliki status gizi baik lebih banyak dibandingkan dengan balita dengan asupan lemak yang kurang. Seperti dilihat pada Tabel 3, hasil uji statistik menujukkan bahwa terdapat hubungan antara asupan lemak dengan status gizi balita $(p=0,010)$. Hal tersebut sesuai dengan penelitian yang dilakukan di Desa Nelayan Puger Jember, bahwa terdapat hubungan signifikan antara tingkat konsumsi lemak dengan status gizi balita ${ }^{20}$.

Tabel 3. Hasil Tabulasi Silang Asupan Energi, Lemak dan Protein dengan Status Gizi Balita di Desa Suci Tahun 2017

\begin{tabular}{|c|c|c|c|c|c|}
\hline \multirow{3}{*}{$\begin{array}{c}\text { Asupan } \\
\text { Balita }\end{array}$} & \multicolumn{4}{|c|}{ Status Gizi Balita } & \multirow{3}{*}{ P value } \\
\hline & \multicolumn{2}{|c|}{ Gizi Kurang } & \multicolumn{2}{|c|}{ Gizi Baik } & \\
\hline & $n$ & $\%$ & $\mathrm{n}$ & $\%$ & \\
\hline \multicolumn{6}{|l|}{ Energi } \\
\hline Cukup & 5 & 38,5 & 39 & 79,6 & \multirow{3}{*}{0,007} \\
\hline Kurang & 8 & 61,5 & 10 & 20,4 & \\
\hline Total & 13 & 100,0 & 49 & 100,0 & \\
\hline \multicolumn{6}{|l|}{ Lemak } \\
\hline Cukup & 3 & 23,1 & 31 & 63,3 & \multirow{3}{*}{0,010} \\
\hline Kurang & 10 & 76,9 & 18 & 36,7 & \\
\hline Total & 13 & 100,0 & 49 & 100,0 & \\
\hline \multicolumn{6}{|l|}{ Protein } \\
\hline Cukup & 12 & 92,3 & 31 & 63,3 & \multirow{3}{*}{0,039} \\
\hline Kurang & 1 & 7,7 & 18 & 36,7 & \\
\hline Total & 13 & 100,0 & 49 & 100,0 & \\
\hline
\end{tabular}


Asupan lemak yang berasal dari
makanan apabila kurang maka akan berdampak pada kurangnya asupan kalori atau energi untuk proses aktivitas dan metabolisme tubuh. Asupan lemak yang rendah diikuti dengan berkurangnya energi di dalam tubuh akan menyebabkan perubahan pada massa dan jaringan tubuh serta gangguan penyerapan vitamin yang larut dalam lemak ${ }^{7}$. Lemak merupakan zat gizi makro yang berfungsi sebagai penyumbang energi terbesar, melindungi organ dalam tubuh, melarutkan vitamin dan mengatur suhu tubuh.

Kelebihan yang dimiliki dalam penelitian ini adalah masih terbatasnya kajian tentang analisis masalah gizi kurang yang terjadi di Kabupaten Gresik yang sebenarnya merupakan Kabupaten dengan tingkat pertumbuhan industry cukup tinggi di Indonesia.

Namun demikian, penelitian ini memiliki kelemahan yaitu metode yang digunakan dalam menanyakan tingkat asupan zat gizi balita menggunakan food recall yang bergantung pada ingatan responden (ibu balita) sehingga dapat meningkatkan terjadinya bias dalam melaporkan bahan makanan yang dikonsumsi balita selama 24 jam terakhir. Hal tersebut dapat diminimalisir dengan menggunakan alat bantu seperti buku gambar makanan atau food model pada saat wawancara.

\section{KESIMPULAN}

Balita dengan status gizi kurang memiliki tingkat kecukupan asupan energi, protein dan lemak lebih rendah dibandingkan dengan balita dengan status gizi baik. Terdapat hubungan antara asupan energi, protein dan lemak dengan status gizi balita. Diperlukan peningkatan bahan makanan sumber energi (nasi, mie, roti dan umbi-umbian), tinggi protein(ikan, daging, telur, kacang-kacangan) dan lemak yang tinggi(menyajikan makanan dengan digoreng, menambahkan makanan dengan minyak goreng atau margarin) serta bahan makanan yang bervariasi agar tidak memperburuk kejadian gizi kurang pada balita. Kelemahan dalam penelitian terkait bias dalam food recall makanan dapat diminimalisir dengan menggunakan alat bantu food model saat melakukan wawancara.

\section{ACKNOWLEDGEMENT}

Terima kasih dan penghargaan diberikan penulis kepada seluruh staf pengajar program studi ilmu gizi Universitas Airlangga atas bimbingan yang telah diberikan.

\section{REFERENSI}

1. Departemen Gizi dan Kesehatan Masyarakat Fakultas Kesehatan Masyarakat Universitas Indonesia. Gizi dan Kesehatan Masyarakat. Jakarta: PT Raja Grafindo Persada. 2010.

2. Marimbi, H. Tumbuh Kembang, Status Gizi, dan Imunisasi Dasar Pada Balita. Yogyakarta: Nuha Medika. 2010.

3. Dinas Kesehatan Kota Gresik.Profil Dinas Kesehatan Kabupaten Gresik Tahun 2012-2015. 2015. Available fromhttp://www.pusdatin.kemkes.go.id /resources/Jatim_Kab_Gresik. Diakses pada 30 Juli 2017.

4. UNICEF. The State Of The World's Children 2016. Available from https://www.unicef.org/sowc2016/ diakses pada 5 Agustus 2017.

5. Almatsier, S. Prinsip Dasar Ilmu Gizi. Jakarta: PT Gramedia Pustaka Utama. 2010.

6. Lutviana, E., Budiono, I. Prevalensi Dan Determinan Kejadian Gizi Kurang Pada Balita. Jurnal Kesehatan Masyarakat. 2010;5(2):138-144. Available from http://journal.unnes.ac.id/index.php/ke mas. Diakses pada 5 Agustus 2017].

7. Barasi, M., Nutrition At A Glance. Penerjemah: Hermin. 2009. At A Glance : Ilmu Gizi. Jakarta: Erlangga. 2007. 
8. Sulistya, H., Sunarto. Hubungan Tingkat Asupan Energi dan Protein dengan Kejadian Gizi Kurang Anak Usia 2-5 Tahun. Jurnal Gizi Universitas Muhammadiyah Semarang. 2013;2(1):25-30.

9. Eunice, A., D. Sarah. An assessment of The Nutritional Status of Under Five Children in Four Districts in The Central Region of Ghana. Asian Journal of Agriculture and Rural Development. 2013;3:851-860. Available from http://ageconsearch.umn.edu/record/1 98311 diakses pada 5 Agustus 2017.

10. Rodriguez, L.C.E., Ortiz, R. Malnutrition and Gastroinstestinal and Respiratory Infections in Children: A Public Health Problem, International Journal of Environmental Research and Public Health. 2011; 8:1174 - 205. Available from

https://www.ncbi.nlm.nih.gov/pmc/artic les/PMC3118884/ diakses pada 5 Agustus 2017.

11. Gewa, A.C., Y. Nannette. Undernutrition Among Kenyan Children: Contribution of Child, Maternal, and Household Factors. Public Health Nutrition. 2012;15:2938. Available from https://www.ncbi.nlm.nih.gov/pubmed/ 22107729 diakses pada 5 Agustus 2017.

12. Ariningsih, E., Rahman, H.P.S. Strategi Peningkatan Ketahanan Pangan Rumah Tangga Rawan Pangan. Jurnal Analisis Kebijakan Pertanian. 2008;6(3):239-255.

13. Gewa, A.C., Leslie, F.T. Distribution and Determinan of Young Child Feeding Practices id Lesn the East African Region: Demographic Health Survey Data
Analysis From 2008 - 2011. Journal of Health, Population and Nutrition. 2015;34:(6).

14. Bharati, S., Chakrabarty, S., Som, S., Pal, M., Bharati, P. Socio-economic Determinant of Underweight Children in West Bengal, India. Asian Pasific Journal of Tropical Medicine. 2010;322-327. Available from http://www.sciencedirect.com/science/ article/pii/S1995764510600788 diakses pada 5 Agustus 2017.

15. Sepehri, A., Gulian H. Socioeconomic Status and Children Health: Evidence From A Low Income Country. Science and Medicine Journal. 2015. 130:23-31. Available from https://www.ncbi.nlm.nih.gov/pubmed/ 25658625 diakses pada 5 Agustus 2017.

16. Asrar, M., Hadi, H., Boediman, D. Pola Asuh, Pola Makan, Asupan Zat Gizi dan Hubungannya dengan Status Gizi Anak Balita Masyarakat Suku Nualau di Kecamatan Amahai Kabupaten Maluku Tengah Provinsi Maluku. Jurnal Gizi Klinik Indonesia. 2009;6(2):84-94.

17. Rahim, K.F. Faktor Resiko Underweight Balita Umur 7 - 59 Bulan. Jurnal Kesehatan Masyarakat. 2014;9(2):115121.

18. Gibney, Michael J., Margetts, Barrie M., Kearney, John M., Arab Lenore. Gizi Kesehatan Masyarakat. Jakarta : Penerbit buku kedokteran EGC. 2009.

19. Hapsari, D., Supraptini, Hananto, M. Faktor- Faktor Pencemaran Udara dalam Rumah Tangga yang Berhubungan dengan Kejadian ISPA pada Balita di Indonesia. Jurnal Ekologi Kesehatan. 2010;9(2):1238-47. 
20. Nurcahyo K., Briawan D. Konsumsi Pangan, Penyakit Infeksi, dan Status Gizi Anak Balita Pasca Perawatan Gizi
Buruk. Jurnal Gizi dan Pangan. 2010;5(3):164-70. 